\title{
Staff Assignment Planning Design for Audit of Non-Profit and Public Institutions
}

\author{
Azza Nadia Mustika Rianti *, Dwi Setiawan Susanto \\ Department of Accounting, Universitas Indonesia, Depok, Indonesia \\ ${ }^{*}$ Corresponding author. Email: azza.nadiamr@gmail.com
}

\begin{abstract}
This paper provides an overview of the use of staffing assignments for the audit planning of non-profits and public institutions. This is a qualitative case study which results show that audit preparation has not been adequate because of the utilization and dissemination of non-optimal information. So, we propose to optimize audit assignments by using extant data and quality information owned by the work unit.
\end{abstract}

Keywords: Staff assignments, Audit planning, Management accounting

\section{INTRODUCTION}

Audit activities apply to both private and public sectors, including the government and non-profits. Their purpose is to provide various types of assurances to help ensure orderly, lawful, effective, transparent, and responsible practices on the management of state finances. Audit standards are established by the Supreme Audit Board and are conducted freely and independently. Consequently, there are several audit that conducted by the Supreme Audit Board such as financial audit, performance audit, and specificobjective audits.

The audit process begins by identifying audit targets, followed by planning and implementation. All audits use established schedules and methods resulting in official reports. The audit is conducted freely and independently, therefor The Supreme Audit Broad could determine their plan by allocating the resources that they have. During the planning stage, several activities take place, including the formation of an audit planning team, preparation of an audit program, preparation of individual work assignments, and a documentmanagement process. These activities are based on government guidelines by BPK. Unfortunately, there is a scarcity of qualified auditors to work on public sector areas. Therefore, to achieve national audit objectives, the resources must be managed more effectively.

The problem is that the government's Supreme Audit Board, an official external auditor of public and non-profit entities, has too few resources to accomplish national objectives. Because of the scarcity of the resource, Supreme Audit Board have to optimized their use of the resources. Therefor our research purpose is to determine whether human resources are efficiently utilized.

\section{LITERATURE REVIEW}

\subsection{Supreme Audit Board Planning}

Audit planning is designed to ensure effective and efficient adherence to standards set by the Supreme Audit Board. Artifacts generated during the planning stage include an audit program and an assignment letter. The scope of these document cover technical preparation and audit support activities. There are four stages of audit planning, as follows:

1. Establishment of an audit planning team

2. Arrangement of an audit program package

3. Preparation of individual work programs

4. Arrangement of audit support

There are several inputs to be considered when making auditing staff assignments, such as the nature (e.g., process and risk) of the entity and the human resource data such as HR profiles. This information is utilized to structure and leverage the appropriate expertise to fully understand requirements and to conducting a thorough audit. 


\subsection{Performance Management}

Performance management (Armstrong, 2006) is a systematic process of improving organizational performance by developing personnel and team performance. The objective is to achieve better organizational results by measuring performance per business objectives, standards, and competencies. Schwartz (1999) explained that the purpose of a successful performance management system was to inform employees about the areas in which they excelled versus those needing improvement. The goal is to improve performance, productivity, and personal satisfaction

Performance management (Armstrong 2006) is a sustained cycle, per William Deming, in which performance management comprises several basic activities:

1. Plan: decide what to do and how to implement the action

2. Act: carry out the required work in accordance with the plan

3. Monitor: continuously monitor the work that has been accomplished and measure the outcomes to assess progress

4. Review: assess accomplishments and provide advice on what future work and corrective actions

Performance measurement comprises systematic data collection activities that include observing and recording performance-related activities. Performance measurement can be arranged into five steps. The first step prioritizes the work effort into questions about what is to be measured. The second step selects indicators, then the next step is collecting data. The fourth step is analyzing the data and finally, the last step is when the findings are reported. Additionally, throughout the process, the quality of measurement must be considered.

\subsection{Balanced Scorecard}

The balanced scorecard (BSC) complements financial performance measurement based on drivers of future performance. BSC variables are derived from the organization's vision and strategy. Organizational performance is measured from four perspectives: finance, customers, internal business processes, and learning and growth. The four scorecard perspectives seek to achieve equality between short- and long-term goals affecting expected outcomes, performance drivers, and objective and subjective.

BSC application is not exclusive to for-profit companies; they are needed by non-profit and public organizations as well. These entities require measurement systems and strategies to communicate and support strategies. Atkinson and Kaplan (2012) described how non-profit organizations and governments modify their BSC framework by expanding the definition of customers to include resource providers and service recipients. Figure 1 displays the basic theory of managerial accounting analytics, related to this study.

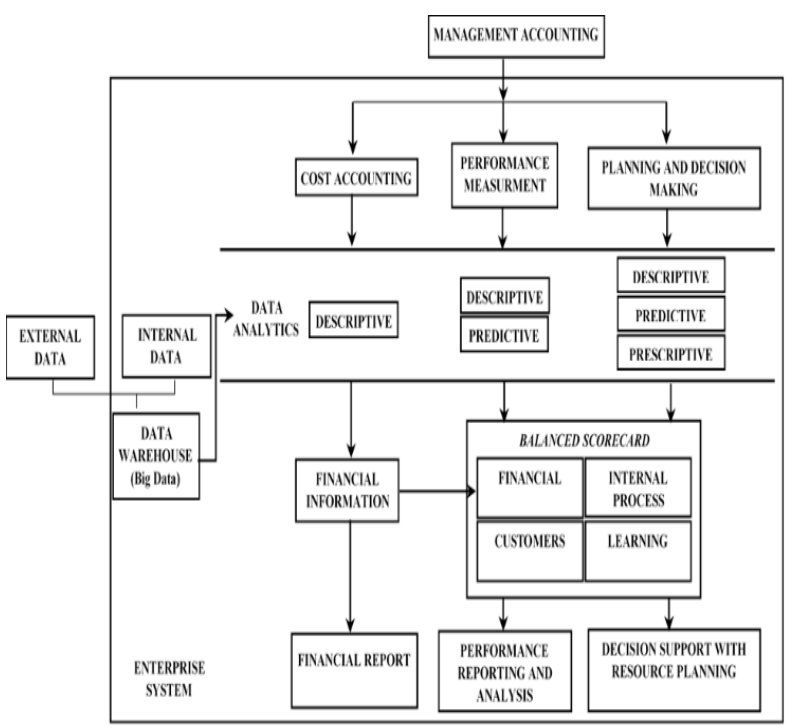

Figure I. Managerial Accounting Data Analytics based on BSC theory

Source: Appelbaum et.al. 2017

Appelbaum et al. (2017) provided a framework for analyzing management accounting data based on the BSC. They explained that management accounting was classified into cost accounting, performance measurement, decision-making, and planning. Cost accounting focuses on the use of internal data to produce organizational financial reports. Performance measurement focuses on insights, decisions, and data analysis of processes or events to measure organizational performance. Data used in measuring performance are either internal or external. Decisionmaking and planning involve the use of results from cost accounting and performance measurement to provide accurate, timely, and relevant information and are combined with other external information to assist management.

\section{RESEARCH METHOD}

This study is a qualitative research that uses a case study method, examining the audit planning process of the Supreme Audit Board of the Republic of Indonesia. The data used for this study come from primary sources, extracted through interviews, observations, and document reviews. Observations were performed at the government work units in Home Office. Interviews were arranged with the Audit Structural Officer whose task was to manage audit resources. We also interviewed secretarial staff involved in the planning stages. 
Secondary data took the form of documents related to audit planning at the ministries and/or public institutions, including regulations related to implementation, policies, yearly work plans, audit plans and programs, and assignment letters. We sought to ascertain how the planning process works, focusing on staff assignments. Our results are linked to data and resource utilization and are compared with performance reports to determine desirable staff assignments. The results can be used for future audit planning processes.

\section{FINDINGS AND ANALYSIS}

\subsection{Analysis of Staff Assignments}

Based on our analysis related to auditor assignments, we found several problems:

1. Managers did not maintain structured data about auditor work experience. There was an information gap between the manager and the secretariat of the work unit.

Managers had difficulty obtaining and managing information related to auditor work experience. New managers tended to struggle with auditor competence, because the information obtained from previous management was often lacking. Based on discussions with secretarial departments, HR management possessed information about auditor background. Thus, the information gap should be bridged.

2. Reports on auditor performance assessment was disingenuous

Auditor performance is to be assessed routinely for staffing audit teams. However, in practice, performance assessments were conducted both formally and informally. Formal assessment were documented, whereas informal assessments were not.

\subsection{Analysis of HR Management}

There were several problems with HR management, as follows:

1. Audit requirements relied on entity size, complexity, specialized skills, auditor independence, audit time, auditor rotation, and personal development.

Based on document analyses and interviews, we found the following:

i. Auditor requirements were not structurally analyzed.

Audit planning steps comprised requirements analysis and role/time allocations. Managers generally did not structurally analyze auditor requirements. They instead allocated auditors per assignment without regard to work unit or expertise. HR Department was the one who apportioned the auditor positions. ii. Auditor assignments were not optimized.

The secretarial unit assigned auditors throughout the year using survey data. If there was a shortage, the secretarial unit then borrowed auditors from other work units.

Table I. Number of Audit Assignment for 2017-2018

\begin{tabular}{|l|l|l|}
\cline { 2 - 3 } \multicolumn{1}{l|}{} & $\mathbf{2 0 1 7}$ & $\mathbf{2 0 1 8}$ \\
\hline Number of Auditors & 134 & 167 \\
\hline $\begin{array}{l}\text { Average of audit assignment/auditor } \\
\text { per year }\end{array}$ & 2.55 & 2.22 \\
\hline $\begin{array}{l}\text { Number of auditors assigned more } \\
\text { than one audit per year }\end{array}$ & 99 & 102 \\
\hline $\begin{array}{l}\text { Number of auditors assigned one } \\
\text { audit per year }\end{array}$ & 35 & 65 \\
\hline
\end{tabular}

Source: Assignment Letter (2017-2018) (BPK RI, 2017-2018). Data processed by the author.

Based on Table I, on average, an auditor was assigned three audits per year. However, some auditors were assigned only one audit per year. Therefore, there were probably idle resources during the year.

2. Auditor Performance Assessment was Managed Based on Individual Performance Guidelines (I.e., MAKIN).

Employee work objectives were quantitative and included work-behavior factors [5]. Our findings on HR competency and performance management of the work units are as follows:

i. Auditors' Performance Measurements were Nonstandard

On average, auditor performance in 2017 and 2018 was measured as "good." Performance assessment comprised elements of work achievement and behavior. Grades were used by management to help determine auditor assignments. Results were captured in formal documents containing assessments per activity. However, results did not reflect actual competence, because the assessments frequently did not include supplementary or external information. Per forum discussions result, the manager usually did not include all information on these reports. Thus, there were two different kinds of information: formal and informal.

ii. Auditor Competencies were Malleable

The State Financial Audit Standards (i.e. SPKN) described required auditor competencies. Auditors must have professional competence that includes education and experience. They must be able to maintain professional skills through a commitment to learning and undertake other training. 
Table II. Summary of Competency Development Report, Year 2017-2018

\begin{tabular}{|l|l|l|}
\cline { 2 - 3 } \multicolumn{1}{c|}{} & $\mathbf{2 0 1 7}$ & $\mathbf{2 0 1 8}$ \\
\hline $\begin{array}{l}\text { Average Training Hours } \\
\text { (hrs/employee) }\end{array}$ & 76 & 65 \\
\hline $\begin{array}{l}\text { Number of Auditors with } \\
\text { Sufficient Training Hours }\end{array}$ & 125 & 115 \\
\hline $\begin{array}{l}\text { Number of Auditor with } \\
\text { Insufficient Training Hours }\end{array}$ & 13 & 28 \\
\hline $\begin{array}{l}\text { Number of Auditor that do not } \\
\text { Participate in Training }\end{array}$ & 5 & 5 \\
\hline
\end{tabular}

Source: Auditor Competency Development Report (2017-2018)(BPK RI, 2017-2018). Data processed by the author.

Based on auditor training reports, we found that, during 2017 and 2018, auditors trained an average 76 and $65 \mathrm{hrs}$, respectively. We also found that some had not fulfilled their required training hours, including some who had attended no training. Based on interviews, auditor competency was achieved in two ways:

1. Via the training activities offered

2. Based on assessment results, including program information required by the auditor.

There was a problem with auditors' availability for training and the limitation of trainings' offers. Furthermore, the competency development program was limited, because it depended on training offers. Hence, auditors frequently suffered calendar conflicts.

\subsection{Recommendation}

We classified the issues related to auditor assignment into two categories: (1) HR utilization and (2) competency information management. We suggest taking advantage of existing reports from work units to synthesize auditor planning assignments. Managers could use a BSC approach to process this information. Appelbaum et al. (2017) described the framework of management accounting data analysis based on BSC from the aspects of performance measurement and decision-making and decision support.

BSC methodology should be implemented based on performance measurements, planning, and decisionmaking, including data analysis as an associated process. Planning and decision-making ostensibly provide optimal solutions (Appelbaum et al. 2017). There are five steps for performance measurement (Van Dooren et al. 2015): prioritize the measurement to be used; determine indicators; collect data; analyze data; and report information. Before determining what to measure, Van Dooren et al. explained that first, we need to comprehend what will be measured.
To increase the capacity of organizational goal achievement, performance information must be leveraged. The following steps are required:

\subsubsection{Identify Valuable Audit Information}

Work units should group valuable information based on four BSC perspectives. If the audit area concerns learning and growth perspectives, it should be aligned with HR management and audit planning. Information related to learning and growth comes from three principles: organization, labor, and information systems.

\subsubsection{Identify Owned Data}

The next step is to identify the data owned by the work units for use in meeting staff requirements: report activities including recapitulation of activities due during the year, audit completion, and follow-up.

i. The Report on Work Unit's Activities - contains information such as:

- Recapitulation of activities during the year

- Completion of audit and the follow-up

ii. The Report on Performance Assessment contains the results of the auditor's performance appraisal.

The measurement is based on MAKIN guidelines. Measurement comprises work goals, behavioral competencies, and technical competencies. Key elements of performance measurement includes audit assignment objectives and professional development requirements.

iii. The Auditor Competency Development Report is related to the development of competencies from training.

The information obtained include undergoes, number of training and hours of the trainings.

iv. HR Data is updated regularly to include a brief background of employees, positions, roles, and experiences.

\subsubsection{Utilize and Distribute Information}

Existing information is sorted into value-added information for auditor assignment planning. Then, the information is adjusted to meet organization's strategic objectives. The Supreme Audit Board uses its Strategic Plan as a reference when conducting audits. The work unit creates a yearly work plan from this based on the year's audit program. This program is used as the basis for resource planning and decision reports. The secretarial unit identifies the auditor requirements based on audit planning. The collected data are then distributed to key managers of the planning program to be used for decision-making. Figure II illustrates the 
BSC being used to determine valuable information to be used for decision support.

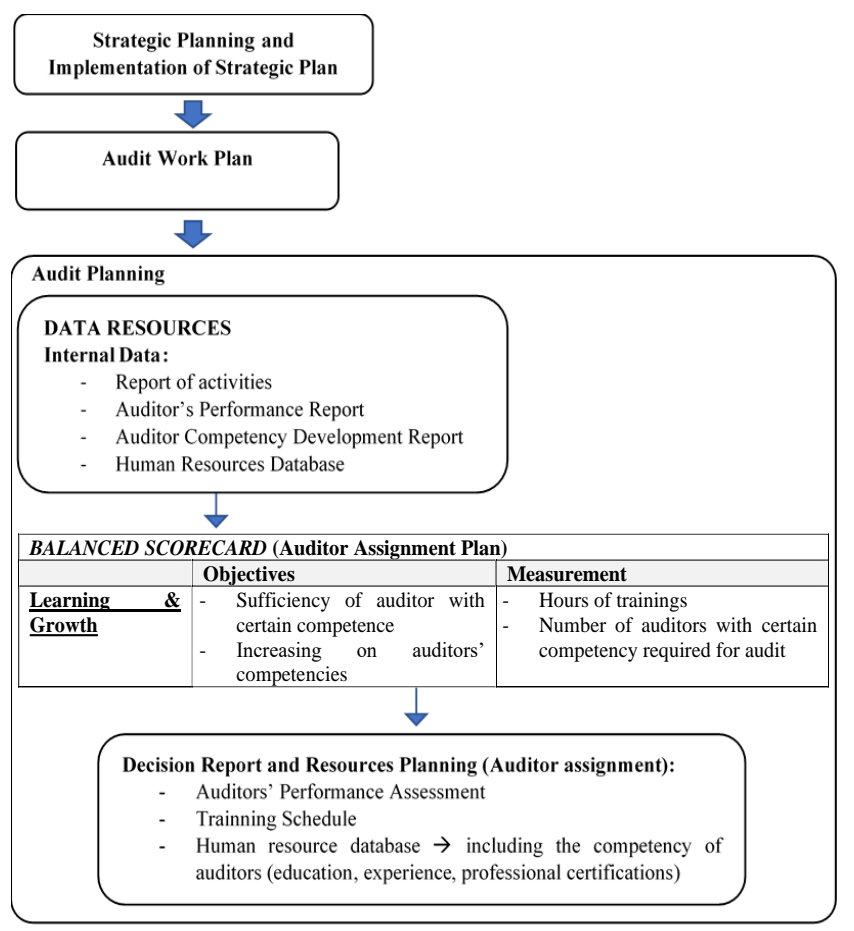

Figure II. Auditor Assignment Plan Using BSC

\section{CONCLUSIONS AND IMPLICATIONS}

There are several problems with the implementation of staff assignments relating to the management and use of information, one of which is related to information about HR input in the formulation of the staff's assignment. Problems related to audit planning include:

- Sub-optimal use and dissemination of information related to HR

- $\quad$ Auditor information sometimes does not reflect the actual conditions.

There are also several problems with HR management:

- $\quad$ Sub-optimal use and utilization of HR

- Inadequate development of HR potential (e.g., training)

We recommend work units optimize staff assignments during the audit planning stage by maximizing the use of internal HR data and the use of communication channels in its dissemination. Auditor assignment planning should be based upon performance reports, focusing on $\mathrm{HR}$ utilization and BSC-driven communication. Planning design includes:

Identification of required planning data using the learning and growth perspective of BSC

- Identification of data owned by the work unit for planning
Communication of information to users via extant communication channels

\section{RESEARCH LIMITATIONS}

This research was limited to one organizational work unit. Thus, it did not provide a generalized perspective. Additionally, our recommendation to optimize HR information only leveraged learning and growth perspectives of the BSC to determining relevant information on staff assignments.

\section{REFERENCES}

[1] Appelbaum, D, Kogan, A, Vasarhelyi, M \& Yan, Z 2017, "Impact of business analytics and enterprise systems on managerial accounting. International," Journal of Accounting Information Systems, vol. 25, pp.29-44. doi:10.1016/j.accinf.2017.03.003

[2] Armstrong, M 2006, Performance management: Key strategies and practical guidelines.

[3] Atkinson, AA, \& Kaplan, R 2012, Management Accounting Edition.

[4] BPK 2014, Keputusan Sekjen BPK RI Nomor 101/K/X-XIII.2/3/2014 tentang Pedoman Manajemen Kinerja Individu pada Pelaksana Badan Pemeriksa Keuangan. Jakarta: Badan Pemeriksa Keuangan Republik Indonesia.

[5] BPK 2015a, Keputusan Badan Pemeriksa Keuangan Republik Indonesia Nomor 5/K/IXIII.2/10/2015 tentang Pedoman Manajemen Pemeriksaan. Jakarta: Badan Pemeriksa Keuangan Republik Indonesia.

[6] BPK 2015b, Keputusan BPK RI Nomor 7/K/IXII.2/12/2015 tentang Rencana Strategis 2016 2020. Jakarta: Badan Pemeriksa Keuangan Republik Indonesia.

[7] BPK 2017a, Keputusan BPK RI Nomor 3/K/IXIII.2/4/2017 tentang Petunjuk Teknis Penilaian Risiko Pemeriksaan Keuangan. Jakarta: Badan Pemeriksa Keuangan Republik Indonesia.

[8] BPK 2017b, Peraturan Badan Pemeriksa Keuangan Republik Indonesia Nomor 1 Tahun 2017 tentang Standar Pemeriksaan Keuangan Negara. Diambil dari http://www.spkn.bpk.go.id. Jakarta: Badan Pemeriksa Keuangan Republik Indonesia.

[9] Kaplan, RS, \& Norton, DP 1996a, The balanced scorecard.

[10] Kaplan, RS, \& Norton, DP 1996b, Linking the balanced scorecard to strategy. California management review, 39(1), 53-79. 
[11] Pemerintah Republik Indonesia 2004, UndangUndang Republik Indonesia Nomor 15 Tahun 2004 Tentang Pemeriksaan Pengelolaan dan Tanggung Jawab Keuangan Negara. Jakarta (ID): RI.

[12] Pusdiklat BPK RI 2017, "Strategi Peningkatan Kualitas Pemeriksaan BPK," 1 Maret 2017. http://pusdiklat.bpk.go.id/?p=10493
[13] Schwartz, AE 1999, Performance management, Barron's Educational Series.

[14] Van Dooren, W, Bouckaert, G, \& Halligan, J 2015, Performance Management in the Public Sector (2nd ed.). New York: Routledge 